\title{
Umur dan Berat Telur Ayam Ras yang Beredar di Kota Bengkulu
}

\author{
Age and weight of layer eggs distributed in Bengkulu \\ Suharyanto \\ Jurusan Peternakan, Fakultas Pertanian, Universitas Bengkulu, Bengkulu \\ Jalan Raya Kandang Limun, Bengkulu.Telp. (0736) 21170. Pst. 219.
}

\begin{abstract}
This study aimed to know eggs storage term, weight and their origin by involving 8 respondents of egg distributor, 10 egg retailers of Pasar Pagar Dewa, 12 egg retailers of Pasar Minggu and 16 egg retailer of Pasar Panorama. Each respondent, both distributor and retail level, was taken as many as 5 eggs to be measured. The result showed that most of the distributors took the egg from producers directly (75\%) and the others obtained from the egg collectors. At the retailers level, some egg supplies were from producer directly (31.6\%). Egg storage term average was 6.69 days at distributors level and 9.78 days at retailers level. The retailers' egg weight was heavier than distributors' where 62.8 grams was at retailers level and 65.6 grams at distributors level
\end{abstract}

Key words: eggs, weight, storage term.

\begin{abstract}
ABSTRAK
Penelitian ini dilakukan untuk mengetahui umur, berat dan asal telur ayam ras yang beredar di pasaran Kota Bengkulu dengan melibatkan 8 responden distributor telur dan 10 orang responden pedagang pengecer Pasar Pagar Dewa, 12 responden pengecer Pasar Minggu dan 16 responden pengecer Pasar Panorama sehingga total responden sebanyak 38 orang. Hasil penelitian menunjukkan bahwa pada umumnya distributor mendapatkan telur dari produsen langsung (75\%) dan sisanya berasal dari pedagang pengumpul di luar Provinsi Bengkulu, ada $31,6 \%$ pengecer yang langsung mendapatkan telur dari produsen di luar Provinsi Bengkulu umur telur rata-rata untuk tingkat distributor adalah 6,69 hari dan tingkat pengecer 9,78 hari. Berat telur rata-rata mengalami penurunan dari tingkat distributor ke pengecer, yaitu dari 65,6 gram menjadi 62,8 gram.
\end{abstract}

Kata Kunci: Telur, berat, umur simpan.

\section{PENDAHULUAN}

Salah satu jenis telur yang paling banyak dikonsumsi oleh warga Bengkulu adalah telur ayam ras. Hal ini mungkin karena ketersediaan telur ini relatif lebih kontinyu dengan harga yang relatif lebih terjangkau dibandingkan dengan telur jenis lain. Data statistik memperlihatkan bahwa konsumsi telur ayam ras masyarakat Kota Bengkulu pada tahun 2002 mencapai 1.922,83 ton atau sebanyak 90,7\% dari total konsumsi telur (Dinas Peternakan dan Keswan Provinsi Bengkulu, 2003).
Dari sebanyak $1.922,83$ ton telur ayam ras yang dikonsumsi pada tahun 2002, sebanyak $1.841,71$ ton $(95,78 \%)$ adalah telur impor dari luar daerah Bengkulu (Dinas Peternakan dan Keswan Provinsi Bengkulu, 2003).

$$
\text { Jarak dan saluran tataniaga }
$$
mempengaruhi umur telur pada konsumen yang pada gilirannya mempengaruhi kualitas telur konsumsi. Hal ini karena telur yang dikeluarkan dari kloaka segera mengalami perubahan kandungan internal dan strukturnya. Perubahan-perubahan ini terjadi 
secara irreversible dan terus menerus sekalipun telur disimpan dalam keadaan dan kendali yang baik (Anonimous, 2005a).

Buckle, et al. (1987) menyebutkan bahwa selama penyimpanan telur utuh mengalami perubahan-perubahan berupa berkurangnya berat, bertambahnya ukuran ruang udara, menurunnya berat jenis karena bertambah besarnya ruang udara, menurunnya jumlah putih telur (albumen) tebal, bertambahnya ukuran kuning telur, dan kenaikan $\mathrm{pH}$ telur.

Scott dan Silversides (2000) juga menyebutkan bahwa semakin lama periode penyimpanan telur mengakibatkan berat dan tinggi putih telur lebih rendah sementara $\mathrm{pH}$ putih telur menjadi lebih tinggi. Hasil penelitian Jones and Musgrove (2004) juga memperlihatkan bahwa selama penyimpanan, berat telur menurun dari kira-kira 61 gram menjadi 57 gram setelah 10 minggu penyimpanan.

Berdasarkan paparan di atas menunjukkan bahwa selama penyimpanan kualitas telur mengalami penurunan. Oleh karena itu perlu diketahui asal usul telur, umur simpan dan berat telur yang beredar di Kota Bengkulu. Variabelvariabel tersebut berpengaruh pada kualitas telur.

\section{MATERI DAN METODE}

Penelitian ini merupakan survei dengan melibatkan 8 orang responden distributor, 10 orang responden pedagang pengecer Pasar Pagar Dewa, 12 responden pengecer Pasar Minggu dan 16 responden pengecer Pasar Panorama sehingga total responden sebanyak 38 orang. Pada masing-masing responden diberi kuesioner untuk menjaring informasi umur telur dan kemudian diambil sebanyak 5 butir telur untuk diukur berat telur.

Analisis data dilakukan secara deskriptif dengan menguraikan keterkaitan antar variabel dengan keberadaan telur.

\section{HASIL DAN PEMBAHASAN}

\section{Umur Telur}

Pada penelitian ini, variabel umur telur menunjukkan adanya 2 (dua) skenario, yaitu umur tercepat dimana telur langsung terjual dan umur terlama dimana telur paling terakhir terjual. Namun demikian, pada pembahasan selanjutnya lebih menekankan pada rataan dari kedua skenario, yaitu ratarata lamanya waktu antara skenario pertama dengan skenario kedua.

Pada tingkat distributor, rata-rata umur telur di tangannya telah berumur 6,69 hari (Tabel 1). Angka ini merupakan rata-rata kisaran 4-13 hari. Dengan kata lain bahwa rata-rata telur paling cepat berada $\mathrm{di}$ distributor adalah telah berumur 4 hari dan rata-rata telur paling lama berada di ditributor adalah telah berumur 13 hari. Semua responden menunjukkan bahwa umur terpendek berkisar antara 2-6 hari dengan rata-rata 3 hari (skenario 1). Sementara pada umur telur terlama berkisar antara $6-20$ hari dengan rata-rata 10,38 hari (skenario 2).

Tabel 1. Umur telur pada tingkat distributor

\begin{tabular}{lrrr}
\hline & Skenario 1 & Skenario 2 & rata-rata kedua skenario \\
\hline Tertinggi (hari) & 6,00 & 20,00 & 13,00 \\
Terendah (hari) & 2,00 & 6,00 & 4,00 \\
Rata-rata (hari) & 3,00 & 10,38 & $\mathbf{6 , 6 9}$ \\
\hline
\end{tabular}

Pada tingkat semua pengecer, rata-rata telur telah berumur 9,78 hari. Angka ini merupakan ratarata kisaran 6,50-17 hari (Tabel 2). Berdasarkan skenario 1 menunjukkan rata-rata telur telah berumur 7,38 hari dengan kisaran 5-15 hari. Bila dilihat berdasarkan skenario 2, rata-rata 
telur telah berumur 12,17 hari dengan kisaran 6,5 20 hari.

Bila dilihat berdasarkan pasar, rata-rata umur telur di pasar Panorama adalah 8,84 hari, Pasar Minggu 9,33 hari dan Pasar Pagar Dewa adalah 11,80 hari (Tabel 2). Perbedaan rata-rata umur telur pada masing-masing pasar tersebut diduga karena pengaruh perbedaan tingkat laku telur pada masing-masing pasar dan umur telur pada tingkat distributor. Untuk pengecer di Pasar Panorama, kebanyakan mereka mendapatkan telur dari distributor yang rata-rata umur telurnya relatif masih pendek dan beberapa pengecer (5 orang) mendapatkan telur secara langsung dari produsen. Berbeda dengan pengecer Pasar Pagar Dewa, selain kebanyakan mendapatkan telur dari distributor yang ratarata umur telurnya relatif lebih lama juga hanya ada 1 orang yang membeli langsung dari produsen. Dengan demikian maka diperkirakan umur telurnya menjadi relatif lebioh lama daripada pengecer Pasar Panorama.

Tabel 2. Umur telur pada tingkat pengecer

\begin{tabular}{|c|c|c|c|}
\hline Waktu & Skenario 1 & Skenario 2 & Rata-rata kedua sekenario \\
\hline \multicolumn{4}{|c|}{ Semua Pasar } \\
\hline Tertinggi (hari) & 14,00 & 20,00 & 17,00 \\
\hline Terendah (hari) & 5,00 & 6,50 & 6,50 \\
\hline Rata-rata (hari) & 7,38 & 12,17 & 9,78 \\
\hline \multicolumn{4}{|c|}{ Pasar Panorama } \\
\hline Tertinggi (hari) & 14,00 & 20,00 & 17,00 \\
\hline Terendah (hari) & 5,00 & 7,00 & 6,50 \\
\hline$\underline{\text { Rata-rata (hari) }}$ & 6,34 & 11,34 & 8,84 \\
\hline \multicolumn{4}{|c|}{ Pasar Minggu } \\
\hline Tertinggi (hari) & 14,00 & 17,00 & 15,50 \\
\hline Terendah (hari) & 5,00 & 6,50 & 6,50 \\
\hline$\underline{\text { Rata-rata (hari) }}$ & 6,83 & 11,83 & 9,33 \\
\hline \multicolumn{4}{|c|}{ Pasar Pagar Dewa } \\
\hline Tertinggi (hari) & 14,00 & 20,00 & 17,00 \\
\hline Terendah (hari) & 6,00 & 9,00 & 7,50 \\
\hline Rata-rata (hari) & 9,70 & 13,90 & 11,80 \\
\hline
\end{tabular}

\section{Berat Telur}

Berat telur rata-rata untuk tingkat distributor adalah sebesar 65,6 gram. Berat telur tertinggi sebesar 78,8 gram dan berat terendah sebesar 56,2 gram. Sementara untuk tingkat pengecer pada seluruh pasar, rata-rata berat telurnya adalah sebesar 62,8 gram. Berat tertinggi sebesar 80,1 gram dan terendah sebesar 49,9 gram. Berdasarkan hasil ini menunjukkan bahwa berat telur pada pengecer menunjukkan penurunan dibandingkan dengan berat telur pada tingkat distributor. Hal ini karena umur telur pada tingkat pengecer lebih lama (rata-rata 6,69 hari) dibandingkan dengan umur telur pada tingkat distributor $(9,78$ hari). Hasil ini sesuai dengan teori-teori umum yang menyebutkan bahwa semakin lama umur telur maka beratnya semakin berkurang yang disebabkan hilangnya air albumen, $\mathrm{CO}_{2}, \mathrm{NH}_{3}, \mathrm{~N}_{2}$ dan $\mathrm{H}_{2} \mathrm{~S}$ (Buckle et al., 1987). 
ISSN 1978 - 3000

Tabel 3. Berat telur pada tingkat distributor dan pengecer

\begin{tabular}{ccc}
\hline Berat & Distributor $^{1}$ & Pengecer $^{2}$ \\
\hline Tertinggi (gram) & 78,8 & 80,1 \\
Terendah (gram) & 56,2 & 49,9 \\
Rata-rata (gram) & $\mathbf{6 5 , 6}$ & $\mathbf{6 2 , 8}$ \\
\hline
\end{tabular}

${ }^{1}$ berdasarkan 30 butir telur sample, ${ }^{2}$ berdasarkan 117 butir telur sampel

Bila dikelompokkan berdasarkan berat dan ukuran telur, berat telur dengan rata-rata 65,5 gram menunjukkan pada kategori Jumbo (65 gram ke atas), yaitu $47 \%$. Tetapi bila dilihat pada berat telur terkecil, ini menunjukkan telur pada tingkat distributor ada yang masuk dalam kategori Besar (55-60 gram), yaitu sebanyak 13\% dan Ekstra Besar (60-65 gram) sebanyak 40\%. Sementara itu untuk tingkat pengecer, telur dengan rata-rata beratnya 62,8 gram termasuk dalam kategori Ekstra Berat. Telur yang masuk dalam kategori Jumbo sebesar 31\%, Ekstra Besar ada $38 \%$, Besar ada 23\%, Sedang ada $8 \%$ dan kategori Kecil ada $1 \%$.

Tabel 4. Persentase kategori telur berdasarkan berat

\begin{tabular}{lcc}
\hline \multicolumn{1}{c}{ Kategori } & Distributor & Pengecer $^{2}$ \\
\hline Jumbo (> 65 gram) & $47 \%$ & $31 \%$ \\
Ekstra Besar (60 - 65 gram) & $40 \%$ & $38 \%$ \\
Besar (55 - 60 gram) & $13 \%$ & $23 \%$ \\
Sedang (50 - 55 gram) & 0 & $8 \%$ \\
Kecil (45 - 50 gram) & 0 & $1 \%$ \\
Sangat Kecil (<45 gram) & 0 & 0 \\
\hline
\end{tabular}

${ }^{1}$ berdasarkan 30 butir telur sample, ${ }^{2}$ berdasarkan 117 butir telur sampel

\section{SIMPULAN}

Berdasarkan hasil dan pembahasan di atas maka dapat disimpulkan bahwa

a. ada $31,6 \%$ pengecer yang langsung mendapatkan telur dari produsen di luar Provinsi Bengkulu

b. umur telur rata-rata untuk tingkat distributor adalah 6,69 hari dan tingkat pengecer 9,78 hari.

c. berat telur rata-rata mengalami penurunan dari tingkat distributor ke pengecer, yaitu dari 65,6 gram menjadi 62,8 gram

\section{DAFTAR PUSTAKA}

Anonimous, 2005a. Egg Quality Guide. http://www.defra.gov.uk/foodrin/poultry/pdfs/eggq ual.pdf, 11 Januari 2005

Jurnal Sain Peternakan Indonesia Vol. 2, No 1, Januari - Juni 2007
Anonimous, 2005b. Spray Sanitaizing Hatching Eggs.http://hatcheryoffice.com/egg_handling/s praysanitv1.3.pdf, 2 Februari 2005.

Buckle, K.A., R.A. Edwards, G.H. Fleet, dan M. Wootton, 1987. Ilmu Pangan. UI-Press. Jakarta.

Butcher, G.D. and R.D. Miles, 2005. Egg Specific Gravity - Designing A Monitoring Program. http://www.afn.org/ poultry/flkman5.htm, 11 Januari 2005

Dinas Peternakan dan Kesehatan Hewan propinsi Bengkulu, 2003. Statistik Peternakan 2002. Dinas Peternakan dan Kesehatan Hewan Propinsi Bengkulu, Bengkulu.

Jacob, J.P., R.D. Miles, dan F.B. Mather, 2005. Egg Quality.

http://edis.ifas.ufl.edu/pdffiles/PS/PS02000.pdf , 11 Januari 2005 
Jones, D.R. dan M.T. Musgrove. 2004. Effects of Extended Storage on Egg Quality Factors. [abstract] Poultry Science Association.

Priyanto, S., 2005. Analisis Permintaan dan Tataniaga Telur Ayam Ras di Kota Bengkulu. Skripsi, Fakultas Pertanian Universitas Bengkulu, Bengkulu (Tidak dipublikasikan)

Sarwono B., 1995. Pengawetan dan Pemanfaatan Telur. Penebar Swadaya, Jakarta.
Scott TA and F.G. Silversides, 2000. The effect of storage and strain of hen on egg quality. Poult Sci. 2000 Dec;79(12):1725-9.

Stadelman, W.J., 1977. Quality Preservation of Shell Eggs. In William J. Stadelman and Owen J. Cotterill (ed), 1977. Egg Science and Technology Second Edition. Avi Publishing Company, Inc., Westport Connecticut. 